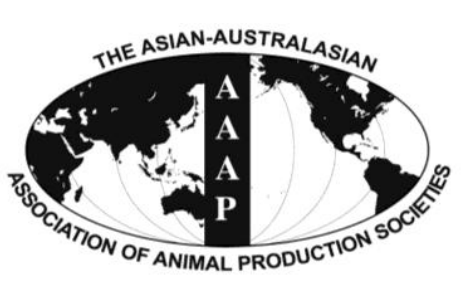

Open Access

Asian Australas. J. Anim. Sci.

Vol. 28, No. 1 : 127-134 January 2015

http://dx.doi.org/10.5713/ajas.14.0582

www.ajas.info

pISSN 1011-2367 elSSN 1976-5517

\title{
Effects of Castration on Expression of Lipid Metabolism Genes in the Liver of Korean Cattle
}

\author{
Myunggi Baik ${ }^{1,2, a, *}$, Trang Hoa Nguyen ${ }^{3, a}$, Jin Young Jeong ${ }^{4}$, Min Yu Piao ${ }^{1,2}$, and Hyeok Joong Kang ${ }^{1,2}$ \\ ${ }^{1}$ Department of Agricultural Biotechnology and Research Institute of Agriculture and Life Sciences, \\ College of Agriculture and Life Sciences, Seoul National University, Seoul 151-921, Korea
}

\begin{abstract}
Castration induces the accumulation of body fat and deposition of intramuscular fat in Korean cattle, resulting in improved beef quality. However, little is known about the metabolic adaptations in the liver following castration. To understand changes in lipid metabolism following castration, hepatic expression levels of lipid metabolism genes were compared between Korean bulls and steers. Steers had higher $(\mathrm{p}<0.001)$ hepatic lipids contents and higher $(\mathrm{p}<0.01)$ mRNA levels of lipogenic acetyl-CoA carboxylase. This differential gene expression may, in part, contribute to increased hepatic lipid content following the castration of bulls. However, we found no differences in the hepatic expression levels of genes related to triglyceride synthesis (mitochondrial glycerol-3-phosphate acyltransferase, diacylglycerol O-acyltransferase 1 and 2) and fatty acid (FA) oxidation (carnitine palmitoyltransferase $1 \mathrm{~A}, \mathrm{C}-4$ to C-12 straight chain acyl-CoA dehydrogenase, very long chain acyl-CoA dehydrogenase) between bulls and steers. No differences in gene expression for very-low-density lipoprotein (VLDL) secretion, including apolipoprotein B mRNA and microsomal triglyceride transfer protein (MTTP) protein, were observed in the liver although MTTP mRNA levels were higher in steers compared to bulls. In conclusion, FA synthesis may contribute to increased hepatic lipid deposition in steers following castration. However, hepatic lipid metabolism, including triglyceride synthesis, FA oxidation, and VLDL secretion, was not significantly altered by castration. Our results suggest that hepatic lipid metabolism does not significantly contribute to increased body fat deposition in steers following castration. (Key Words: Korean Cattle, Liver, Bulls, Steers, Gene Expression)
\end{abstract}

\section{INTRODUCTION}

In Korean cattle as well as other cattle breeds, meat quality is the economically important trait, and intramuscular fat (IMF) content or marbling in the longissimus dorsi muscle (LM) tissue is one of most important parameters influencing beef quality (Hovenier et al., 1993; Hausman et al., 2009; KAPE, 2014). Marbling is

* Corresponding Author: M. Baik. Tel: +82-2-880-4809, Fax: +82-2-873-2271, E-mail: mgbaik@ snu.ac.kr

${ }^{2}$ Institute of Green Bio Science Technology, Pyeungchang 232916, Korea.

${ }^{3}$ Department of Molecular Biotechnology, Chonnam National University, Gwangju 500-757, Korea.

${ }^{4}$ National Institute of Animal Science, RDA, Suwon 441-706, Korea.

${ }^{a}$ These two authors contribute equally to this work.

Submitted Jul. 31, 2014; Revised Aug. 25, 2014; Accepted Aug. 31, 2014 affected by several factors, such as breed, genotype, age, castration, and nutrition (Maltin et al., 2003). Among these, castration markedly increases the degree of marbling, resulting in improved beef quality in cattle (Park et al., 2002; Bong et al., 2012).

The liver transforms dietary nutrients into the fuels and precursors required by peripheral tissues, and exports them via the blood. The demand of extrahepatic tissues for nutrients varies with the physiological state of animals. The liver has remarkable metabolic flexibility. Bovine animals are characterized by low levels of lipogenesis and a low rate of secretion of very low-density lipoproteins (VLDL) by the liver (Emery et al., 1992). This limited capacity of the bovine liver to secrete VLDL might induce lipid accumulation of the liver under certain conditions. For example, during the periparturient period of high-producing dairy cows, significant amounts of non-esterified fatty acids (NEFA) are transported from adipose tissue to the liver to 
combat negative energy balance (Grummer, 1993). In hepatic cells, NEFA are transformed into ketone bodies or are re-esterified into triglyceride (TG), which are then exported from the liver as VLDL. The TG may accumulate inside the hepatic cells due to low rate of VLDL secretion, resulting in fatty liver.

In our previous study (Bong et al., 2012) as well as other (Park et al., 2002) higher body adiposity including increased IMF deposition and backfat thickness after castration has been observed. These changes may be associated with metabolic adaptation in the liver of steers following castration. However, little is known about metabolic changes in the liver after castration. This study was performed to understand the effect of castration on the hepatic lipid metabolism in Korean cattle. We examined hepatic molecular changes associated with lipid metabolism after castration.

\section{MATERIALS AND METHODS}

\section{Animals}

All experimental procedures were performed in accordance with the Animal Experimental Guidelines provided by the Chonnam National University Institutional Animal Use and Care Committee (CNUIAUCC), Republic of Korea. The experimental protocol was approved by CNUIAUCC.

We used liver tissue samples from 10 bulls and 10 steers from a previous study (Bong et al., 2012). Briefly, Korean bulls were weaned at a mean age of 3 months, and fed $30 \%$ concentrate $/ 70 \%$ roughage until they reached 6 months of age. Some bulls were castrated at 6 months of age. After 6 months of age, both bulls and steers were fed concentrates that consisted of $15 \%$ crude protein $(\mathrm{CP}) / 71 \%$ total digestible nutrient (TDN) until 14 months of age, $13 \%$ $\mathrm{CP} / 72 \%$ TDN until 20 months of age, and 11\% CP/73\% TDN after 21 months of age. Concentrate feed intake levels were about $1.6 \%$ (fed-base) of body weight from 6 to 20 months of age and thereafter ad libitum $(1.1 \%$ to $1.5 \%$ of body weight).

Roughage was offered ad libitum and the animals had free access to fresh water during the entire period. Slaughter ages were 20 months and 28 months for bulls and steers, respectively. Carcass weights were $347 \pm 12$ and $398 \pm 10 \mathrm{~kg}$ for bulls and steers, respectively. Out of 20 steers (Bong et al., 2012), we used the 10 animals with the highest marble scores ( 7 to 9 on a scale of 1 to 9 ) in order to see clear differences in liver metabolism between steers and bulls.

\section{Blood and tissue samples}

For slaughter, animals were transported $4 \mathrm{~h}$ and slaughtered the following day. The animals were kept off feed but were given free access to water. Upon arrival at the abattoir, body weight was determined and used as the live weight. The live weights of the bulls and steers were $611 \pm 42 \mathrm{~kg}$ and $671 \pm 72 \mathrm{~kg}$, respectively. After undergoing captive-bolt stunning, the animals were slaughtered in a conventional manner. Immediately after slaughter, liver tissues were collected, snap-frozen in liquid nitrogen, and stored at $-80^{\circ} \mathrm{C}$.

Blood samples $(10 \mathrm{~mL})$ were collected from the jugular vein into a Vacutainer before slaughter, after fasting $8 \mathrm{~h}$, and chilled to $4^{\circ} \mathrm{C}$. Serum was collected after centrifugation $\left(2,000 \times g, 4^{\circ} \mathrm{C}, 20 \mathrm{~min}\right)$. Serum samples were divided into portions and frozen at $-20^{\circ} \mathrm{C}$.

\section{Blood analysis and hepatic lipid contents}

All serum parameters were determined by the Green Cross Reference Lab (Yongin-si, Republic of Korea). Total cholesterol, high-density lipoprotein (HDL), and lowdensity lipoprotein (LDL) levels were analyzed using an enzymatic colorimetric assay with HDL-C-plus third-generation, and LDL-C-plus second-generation kits (Roche, Penzberg, Upper Bavaria, Germany), respectively.

Total lipids were extracted from liver samples using chloroform-methanol (2:1, v/v) according to the method of Folch et al. (1957). The fat-containing solvents were evaporated and fat content was measured.

\section{RNA isolation and real-time polymerase chain reaction}

Total RNA from tissues was isolated using the TRIzol reagent (Molecular Research Center), according to the manufacturer's protocol. Total RNA was quantified by absorbance at $260 \mathrm{~nm}$, and the integrity of total RNA was checked by agarose gel electrophoresis and ethidium bromide staining of the $28 \mathrm{~S}$ and $18 \mathrm{~S}$ bands. Total RNA (2 $\mu \mathrm{g})$ was reverse-transcribed into cDNA using an iScript cDNA Synthesis kit (Bio-Rad, Hercules, CA, USA), according to the manufacturer's protocol.

Real-time polymerase chain reaction (PCR) was performed using QuantiTect SYBR Green RT-PCR Master Mix (Qiagen, Hilden, Germany) and an Opticon Sequence Detection System (MJ Research, Waltham, MA, USA). Briefly, the PCR was conducted in a $25 \mu \mathrm{L}$ total reaction volume containing $200 \mathrm{ng}$ cDNA, $12.5 \mu \mathrm{L}$ SYBR Green RT-PCR Master Mix, and $1.25 \mu \mathrm{L} 10 \mu \mathrm{M}$ primers. The thermal cycling parameters were: $95^{\circ} \mathrm{C}$ for $15 \mathrm{~min}$, followed by 40 cycles at $94^{\circ} \mathrm{C}$ for $15 \mathrm{~s}, 60^{\circ} \mathrm{C}$ for $30 \mathrm{~s}$, and $72^{\circ} \mathrm{C}$ for $30 \mathrm{~s}$. All primers were designed using integrated DNA technology, based on sequences published in the National Center for Biotechnology Information database (Table 1). The $\Delta \Delta \mathrm{CT}$ method was used to determine the relative fold changes (Livak and Schmittgen, 2001) and all data were normalized using the housekeeping ribosomal protein $\mathrm{S} 9$ gene. 
Table 1. Primers for real-time- polymerase chain reaction analysis

\begin{tabular}{|c|c|c|c|}
\hline Gene name, symbol & GenBank ID & $\begin{array}{c}\text { Sequence } 5^{\prime} \rightarrow 3^{\prime} \\
\text { (Forward } \\
\text { Reverse) }\end{array}$ & $\begin{array}{l}\text { Amplicon size } \\
\text { (bp) }\end{array}$ \\
\hline Fatty acid translocase, CD36 & NM_174010 & $\begin{array}{l}\text { ggtccttacacatacagagttcg } \\
\text { atagcgagggttcaaagatgg }\end{array}$ & 115 \\
\hline Lipoprotein lipase, LPL & NM_001075120 & $\begin{array}{l}\text { cttgccacctcattcctg } \\
\text { acccaactctcatacattcctg }\end{array}$ & 119 \\
\hline Solute carrier family 27 (fatty acid transporter), member 5, FATP5 & NM_001033625 & $\begin{array}{l}\text { gcatggtgtgactgtgatcc } \\
\text { tggaaggtctcccacacttc }\end{array}$ & 141 \\
\hline Acetyl-coenzyme A carboxylase, ACC & NM_174224 & $\begin{array}{l}\text { aggagggaagggaatcagaa } \\
\text { gcttgaacctgtcggaagag }\end{array}$ & 69 \\
\hline Fatty acid synthase, FASN & NM_001012669 & $\begin{array}{l}\text { atcgagtgcatcaggcaagt } \\
\text { tgtgagcacatctcgaaagcca }\end{array}$ & 92 \\
\hline Carnitine palmitoyltransferase $1 \mathrm{~A}$ (liver), CPT1a & XM_002699420 & $\begin{array}{l}\text { catggtagaccccacacaga } \\
\text { ccacgtagaggcagaagagg }\end{array}$ & 134 \\
\hline Acyl-CoA dehydrogenase, C-4 to C-12 straight chain, ACADM & NM_001075235 & $\begin{array}{l}\text { tgcaatgggagcatttgata } \\
\text { ctccagggcatacttggtagc }\end{array}$ & 100 \\
\hline Acyl-CoA dehydrogenase, very long chain, ACADVL & NM_174494 & $\begin{array}{l}\text { ccgtgaccegattctttgag } \\
\text { agaccttgcatggtggtctc }\end{array}$ & 85 \\
\hline Liver X receptor, alpha; LXRa & NM_001014861 & $\begin{array}{l}\text { atgcctacgtctccatccac } \\
\text { gggggaagcttcttatcctg }\end{array}$ & 142 \\
\hline 3-hydroxy-3-methylglutaryl-CoA reductase, HMGCR & NM_001105613 & $\begin{array}{l}\text { cgcaacctttacatccgttt } \\
\text { gtgcatttcggggaaatactc }\end{array}$ & 117 \\
\hline Glycerol-3-phosphate acyltransferase, mitochondrial, GPAM & NM_001012282 & $\begin{array}{l}\text { acgacggaggctagatgaga } \\
\text { ttccacttcttgagcgtgtg }\end{array}$ & 140 \\
\hline Diacylglycerol O-acyltransferase 1, DGAT1 & NM_174693.2 & $\begin{array}{l}\text { tcttccactcctgcctgaac } \\
\text { agtaggtgatggactcggag }\end{array}$ & 96 \\
\hline Diacylglycerol O-acyltransferase 2, DGAT2 & NM_205793 & $\begin{array}{l}\text { cattgccgtgctctacttca } \\
\text { agtttcggacccactgtgac }\end{array}$ & 86 \\
\hline Sterol regulatory element binding transcription factor 1, SREBP1 & NM_001113302 & $\begin{array}{l}\text { accgctcttccatcaatgac } \\
\text { gctgaaggaagcggatgtag }\end{array}$ & 120 \\
\hline Apolipoprotein B, ApoB & XM_002691511 & $\begin{array}{l}\text { tcgaaggtggcatgttagtg } \\
\text { ttgggctggtgatgttaagg }\end{array}$ & 138 \\
\hline Microsomal triglyceride transfer protein, MTTP & NM_001101834 & $\begin{array}{l}\text { caagcaaaatggtccgtcaag } \\
\text { tgtaagtagatgccgaatgg }\end{array}$ & 129 \\
\hline Retinoid $\mathrm{x}$ receptor alpha, $\mathrm{RXR} \alpha$ & XM_002691687 & $\begin{array}{l}\text { aagaccgagacctacgtgga } \\
\text { tccaccagtgtgaagagctg }\end{array}$ & 116 \\
\hline Retinoid $\mathrm{x}$ receptor beta, $\mathrm{RXR} \beta$ & NM_001083640 & $\begin{array}{l}\text { gcatccetggagacctactg } \\
\text { gcctatggacctgagagcag }\end{array}$ & 96 \\
\hline Retinoid X receptor gamma, $\mathrm{RXR} \gamma$ & NM_001075408 & $\begin{array}{l}\text { atgaagatatgcccgtggag } \\
\text { cagcgtggcatatattggtg }\end{array}$ & 126 \\
\hline Ribosomal protein S9, RPS9 & NM_001101152 & $\begin{array}{l}\text { cctcgaccaagagctgaag } \\
\text { cctccagacctcacgtttgttc }\end{array}$ & 64 \\
\hline
\end{tabular}

\section{Western blot analysis}

Samples were homogenized in a Polytron homogenizer for $30 \mathrm{~s}$ in modified cold RIPA buffer containing protease inhibitors $\quad(50 \mathrm{mM}$ Tris-Cl, $\mathrm{pH} \quad 7.5, \quad 1 \%$ sodium deoxycholate, $1 \%$ Nonidet P-40, $0.1 \%$ sodium dodecyl sulfate, $150 \mathrm{mM} \mathrm{NaCl}, 1 \mathrm{mM}$ phenylmethylsulfonyl fluoride, $1 \mu \mathrm{g} / \mathrm{mL}$ leupeptin, $1.6 \mu \mathrm{g} / \mathrm{mL}$ aprotinin, $1 \mathrm{mM}$ dithiothreitol, $50 \mathrm{mM}$ sodium fluoride, $10 \mathrm{mM}$ sodium vanadate), and the homogenized samples were incubated at $4^{\circ} \mathrm{C}$ for $30 \mathrm{~min}$. Samples were centrifuged $(10,000 \times g$, $10 \mathrm{~min}, 4^{\circ} \mathrm{C}$ ) and the protein content of each supernatant was determined using the Bradford method. The $40 \mu \mathrm{g}$ of homogenized proteins were separated by SDS-PAGE using $8 \%$ for microsomal TG transfer protein (MTTP; $160 \mathrm{kDa}$ ) and $10 \%$ polyacrylamide separating gel for acyl-CoA dehydrogenase, C-4 to C-12 straight chain (ACADM; 45 
$\mathrm{kDa}$, with 5\% stacking gels. Proteins were transferred to polyvinylidene fluoride membranes, blocked with $1 \times$ phosphate buffered solution/0.1\% Tween 20 and 5\% non-fat dried milk, and analyzed using commercial primary antibodies (1:1,000 dilution), including rabbit polyclonal anti-MTTP (Sigma-Aldrich, Seelze, Germany) and mouse polyclonal anti-ACADM (Santa Cruz Biotechnology, Santa Cruz, CA, USA). The antibodies against MTTP and ACADM cross-reacted with bovine proteins. The blots were treated with secondary horseradish peroxidase-conjugated anti-rabbit or anti-mouse antibodies (1:5,000 dilution; Santa Cruz Biotechnology), and were developed using an enhanced chemiluminescence system (Thermo Scientific, Rockford, IL, USA). The processed blots were exposed to $\mathrm{X}$-ray film, and the autoradiograms were analyzed using a scanner and the GelQuantNET software (http://biochemlabsolutions. com/GelQuantNET.html). Band densities were normalized with the $\beta$-actin content.

\section{Statistical analysis}

All data are presented as means \pm standard errors Statistical differences between bulls and steers were determined using the general linear model procedure of the SAS software (SAS Institute, Cary, NC, USA).

\section{RESULTS}

Hepatic lipid contents and serum cholesterol concentrations

We compared lipid contents in the liver between steers and bulls. Lipid contents were higher in steers (Table 2). We also compared their serum cholesterol concentrations, and found that concentrations of both HDL cholesterol $(p<0.05)$ and LDL cholesterol $(\mathrm{p}<0.01)$ were higher in steers (Table 2). Steers also tended to have higher total cholesterol concentrations than bulls.

Expression levels of genes for lipid uptake, lipogenesis,
Table 2. Hepatic lipid contents and serum cholesterol concentrations in bulls and steers

\begin{tabular}{lccc}
\hline Items & Bulls & Steers & p value \\
\hline Liver & & & \\
$\quad$ Lipid content (mg/g) & $58.2 \pm 1.94$ & $92.6 \pm 3.94$ & $<0.001$ \\
Serum & & & \\
$\quad$ Total cholesterol (mg/dL) & $165 \pm 11.6$ & $196 \pm 8.09$ & 0.09 \\
$\quad$ HDL cholesterol (mg/dL) & $72.4 \pm 4.37$ & $87.1 \pm 2.76$ & 0.02 \\
$\quad$ LDL cholesterol (mg/dL) & $14.8 \pm 1.12$ & $22.2 \pm 1.12$ & 0.002 \\
\hline
\end{tabular}

HDL, high-density lipoprotein; LDL, low-density lipoprotein; SEM, standard error of the mean.

Values shown are means $\pm \operatorname{SEM}(n=10)$.

\section{and cholesterol synthesis}

We compared the expression levels of genes for lipid uptake proteins. Steers had lower $(\mathrm{p}<0.05)$ mRNA levels of lipoprotein lipase (LPL) and fatty acid (FA) transporter 5 (FATP5) in the liver (Figure 1), and tended to have lower Fatty acid translocase (CD36) mRNA levels as well.

Next, we examined the expression of adipogenic transcription factor genes in the liver. Steers had higher $(\mathrm{p}<0.01) \quad$ sterol regulatory element-binding protein-1 (SREBP1) mRNA levels (Figure 2A), higher $(\mathrm{p}<0.05)$ retinoid $X$ receptor $\beta(\operatorname{RXR} \beta)$ mRNA levels, and tended to have higher $\operatorname{RXR} \alpha$ and $\operatorname{RXR} \gamma$ mRNA levels than bulls. They also had higher $(\mathrm{p}<0.01)$ lipogenic acetyl-coenzyme $A$ carboxylase (ACC) mRNA levels (Figure 2B). No difference was observed in hepatic fatty acid synthase (FASN) expression between bulls and steers.

Triglycerides (TG) are the main storage form of FA in the liver and adipose tissue. We examined the expression of TG synthesis genes. Bulls and steers showed similar hepatic mRNA levels of glycerol-3-phosphate acyltransferase, mitochondrial (GPAM) and diacylglycerol O-acyltransferase 1 and 2 (DGAT1 and DGAT2; Figure 2C).

Regarding cholesterol synthesis, steers had lower $(\mathrm{p}<0.05)$ mRNA levels of both liver $\mathrm{X}$ receptor alpha

\section{CD36}

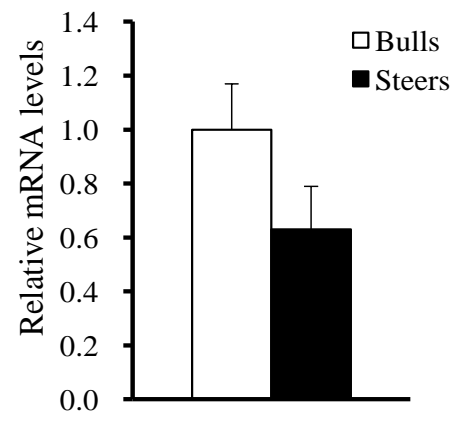

FATP5

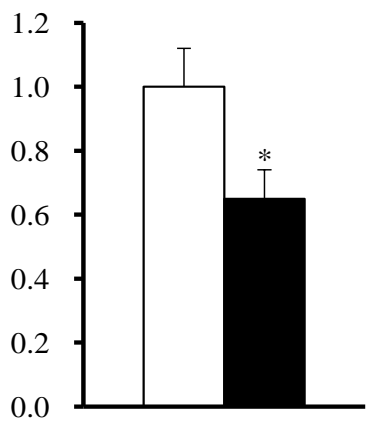

LPL

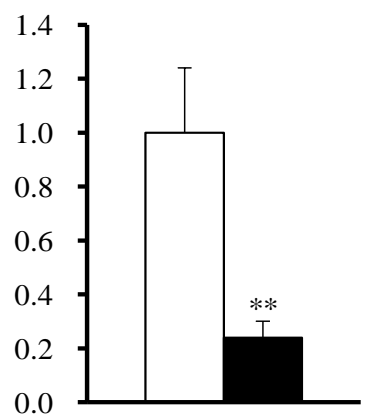

Figure 1. Comparison of mRNA levels of fatty acid uptake and transporter genes between bulls and steers in the liver. mRNA levels were determined by real-time polymerase chain reaction, and results were normalized with the ribosomal protein $\mathrm{S} 9$ gene $(n=10)$. Values of bulls were normalized as 1.0. Values are shown as means+standard error of the means. $* \mathrm{p}<0.05 ; * * \mathrm{p}<0.01$. CD36, CD36 molecule; FATP5, fatty acid transporter 5; LPL, lipoprotein lipase. 
(A) Adipogenesis
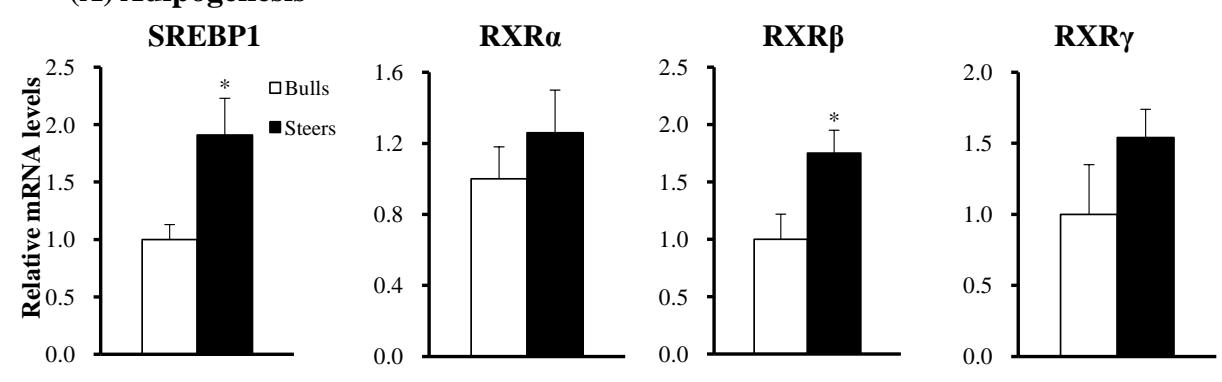

(B) Lipogenesis
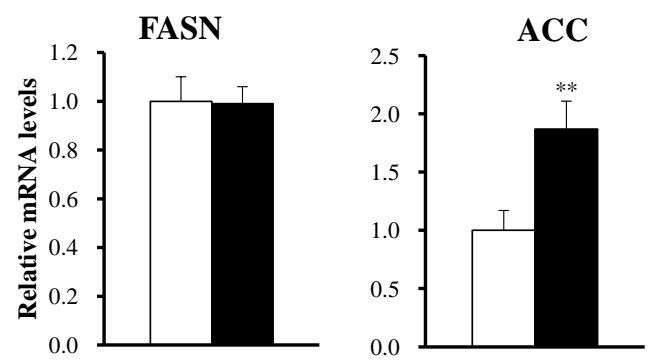

(C) TG synthesis
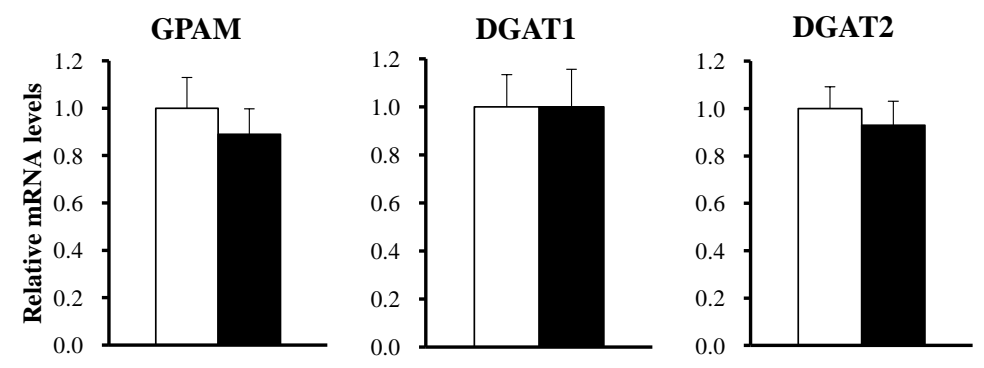

(D) Cholesterol synthesis
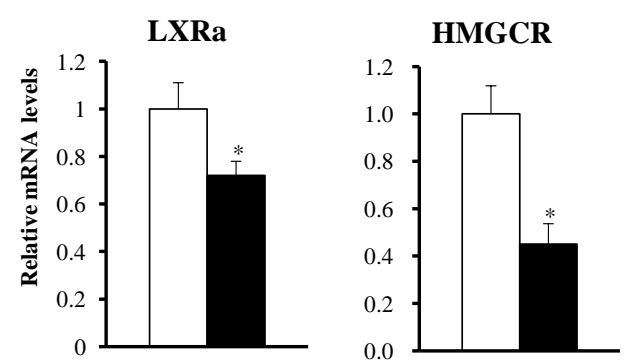

Figure 2. Comparison of mRNA and protein levels of adipogenic (A), lipogenic (B), triglyceride (TG) synthesis (C), and cholesterol synthesis (D) genes between bulls and steers in the liver. mRNA levels were determined by real-time polymerase chain reaction, and the results were normalized with the ribosomal protein S9 gene $(n=10)$. Values of bulls were normalized as 1.0. Values are shown as means+standard error of the means. * $\mathrm{p}<0.05$, ** $\mathrm{p}<0.01$. SREBF1, sterol regulatory element binding transcription factor 1 ; RXR $\alpha$, retinoid X receptor-alpha; RXR $\beta$, retinoid X receptor-beta; $\mathrm{RXR} \gamma$, retinoid X receptor-gamma; FASN, fatty acid synthase; ACC, acetylCoA carboxylase $\alpha$; GPAM, glycerol-3-phosphate acyltransferase; DGAT1, diacylglycerol O-acyltransferase 1; DGAT2, diacylglycerol O-acyltransferase 2; LXR $\alpha$, liver X receptor-alpha; HMGCR, 3-hydroxy-3-methylglutaryl-CoA reductase.

(LXR $\alpha$; Figure 2D) and hepatic 3-hydroxy-3- low-density lipoprotein secretion methylglutaryl-CoA reductase (HMGCR).

We measured expression of FA oxidation genes. Steers had lower $(p<0.05)$ mRNA levels of ACADM than bulls

Expression levels of genes for fatty acid oxidation very (Figure 3A). However, hepatic ACADM protein levels did 
(A) Fatty acid oxidation
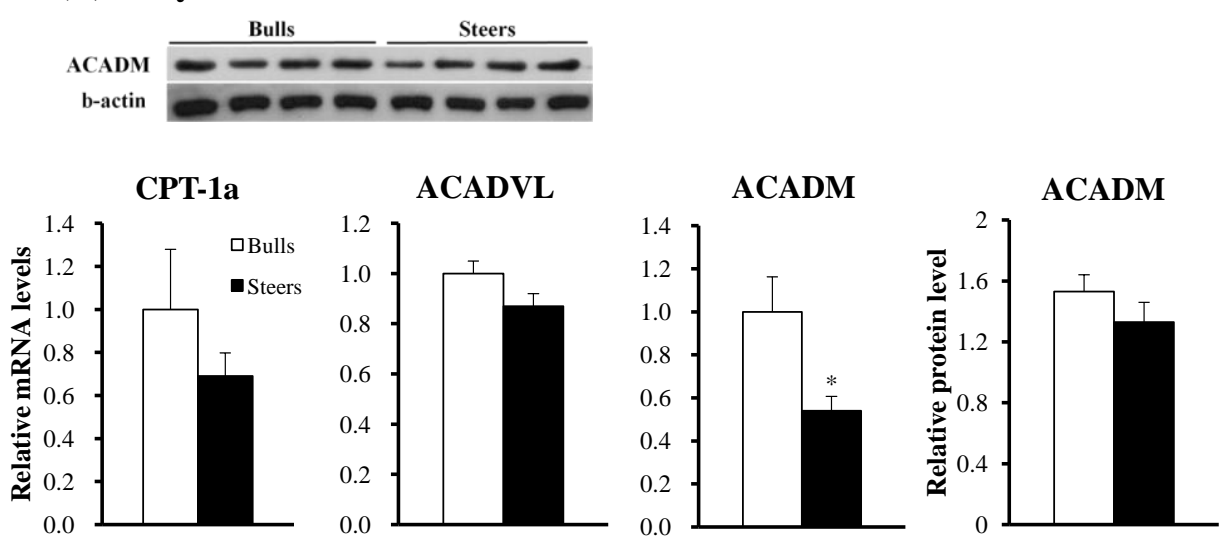

(B) VLDL secretion

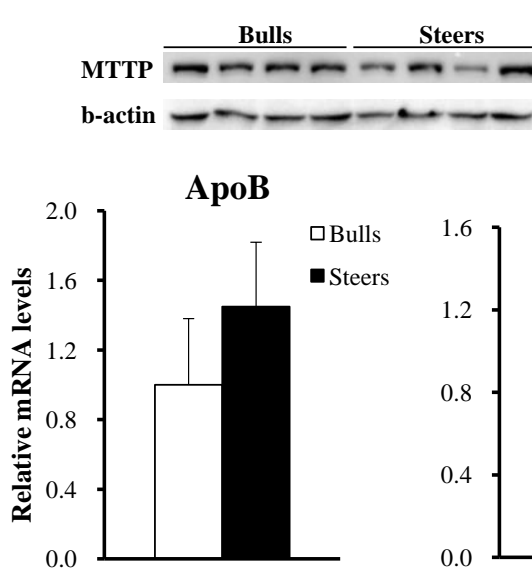

Steers
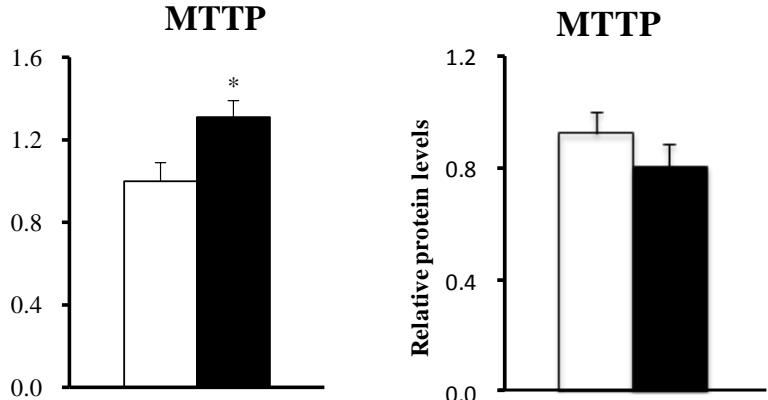

Figure 3. Comparison of expression levels of fatty acid oxidation (A) and very-low-density lipoprotein (VLDL) secretion genes (B) genes between bulls and steers in the liver. mRNA levels were determined by real-time polymerase chain reaction, and they were normalized with the ribosomal protein S9 gene $(n=10)$. Protein levels $(n=4)$ were determined by Western blot analysis and normalized to $\beta$-actin levels. Values of bulls were normalized as 1.0. Values are shown as means+standard error of the means. ${ }^{*} \mathrm{p}<0.05$. CPT-1a, carnitine palmitoyltransferase 1A (liver); ACADVL, acyl-CoA dehydrogenase very long chain; ACADM, acyl-CoA dehydrogenase, C-4 to $\mathrm{C}-12$ straight chain; ApoB, apolipoprotein B; MTTP, microsomal triglyceride transfer protein.

not differ between steers and bulls. Hepatic mRNA levels of carnitine palmitoyltransferase 1A (CTP-1a) and acyl-CoA dehydrogenase, very long chain (ACADVL) were also not different between bulls and steers.

We measured mRNA levels for VLDL secretion genes in the liver. Apolipoprotein B (ApoB) mRNA levels were not significantly different $(\mathrm{p}>0.05)$ between bulls and steers. Steers had higher $(\mathrm{p}<0.05)$ MTTP mRNA levels than bulls (Figure 3B). However, MTTP protein levels were not different $(p>0.05)$ between bulls and steers.

\section{DISCUSSION}

The liver is the central organ for nutrient metabolism and plays a key role in the coordination of nutrient fluxes to support body homeostasis. The nutrient demand of extrahepatic tissues, such as the LM, varies with the physiological state of the animal, and the liver adapts its metabolism to meet various circumstances. Castration of bulls increases the accumulation of body fat, including IMF and subcutaneous fat depots (Bong et al., 2012; Jeong et al., 2013). To understand the liver-related molecular events associated with lipid metabolism following the castration of bulls, we compared hepatic lipid contents and the expression of lipid metabolism genes between bulls and steers.

Steers had higher lipid levels than bulls, demonstrating that castration increased hepatic fat deposition. Liver fat deposition is affected by several lipid metabolism pathways, including FA transport/uptake from the circulating blood, de novo hepatic FA synthesis, FA esterification, FA oxidation, and the export of hepatic TGs via VLDL secretion into the circulation. The FA uptake is regulated by several molecules, such as LPL (Goldberg and Merkel, 2001), CD36 (Love- 
Gregory et al., 2008), and FATPs (Bonen et al., 2007). We found that steers had lower hepatic mRNA levels of LPL and FATP5 than bulls. Steers also tended to have lower CD36 mRNA levels. Thus, the FA uptake/transport pathway does not seem to be a major step regulating hepatic fat accumulation.

We found that steers had higher adipogenic SREBP1 mRNA levels. SREBP1 is one of the most important transcription factors that can mediate the expression of lipogenic genes (Shimano et al., 1999; Anderson and Borlak, 2008). RXRs are nuclear receptor partners of SREBP1 (Anderson and Borlak, 2008). In this study, steers had higher $\operatorname{RXR} \beta$ mRNA levels and tended to have higher $\mathrm{RXR} \alpha$ and RXR $\gamma$ mRNA levels. An important source for hepatic lipid accumulation is de novo FA synthesis, and ACC is a rate-limiting enzyme for the de novo FA synthesis pathway. We found that ACC mRNA levels were higher in steers than bulls. Thus, the increased SREBP1 and RXRs may upregulate transcription of the ACC gene. Taken together, our results demonstrate that increased de novo FA synthesis may contribute to the increased hepatic lipid content in cattle following castration. The increased lipogenesis and hepatic steatosis were observed in androgen receptor knockout mice fed a high-fat diet (Lin et al., 2008). Therefore, decreased androgen signaling by depletion of testosterone secretion, as evidenced by our previous study (Bong et al., 2012), may be one of reasons for increased lipid contents in steers following castration.

We found no difference in the hepatic expression levels of genes related to TG synthesis (GPAM, DGAT1, and DGAT2) between bulls and steers. A previous report suggested that GPAM is not limiting for hepatic TG accumulation in dairy cows (Loor et al., 2006). Another study reported no changes in the activities of DGATs in overfed dairy cows that developed fatty liver (Van Den Top et al., 1995). The present study and those previous results suggest that the TG synthesis pathway is not an important step for hepatic fat accumulation in cattle.

In addition to fat deposition, the fat removal pathway may be important for hepatic fat accumulation. Our study revealed that hepatic mRNA levels of FA oxidation CTP-1a and ACADVL genes and ACADM protein levels did not differ, although ACADM mRNA levels were lower in steers than in bulls. Thus, our results indicate that castration had minor effects on the hepatic expression of FA oxidation genes.

We found that circulating cholesterol concentrations were generally higher in steers than in bulls. Steers had lower HMGCR mRNA levels in the liver. HMGCR is the rate-limiting enzyme for cholesterol synthesis and is regulated via a negative feedback mechanism, mediated by sterols and non-sterol metabolites derived from mevalonate, the product of the reaction catalyzed by reductase (Chen et al., 2012). Thus, lower expression of HMGCR in steers may reflect higher circulating cholesterol concentrations through a negative feedback mechanism. Steers also had lower hepatic mRNA levels of hepatic LXR $\alpha$. The LXRs are nuclear receptors that are activated by endogenous oxysterols, oxidized derivatives of cholesterol (Edwards et al., 2002). Lower LXR mRNA levels may be responsible for the lower HMGCR gene expression in the liver of steers versus bulls.

The TGs and cholesterol in the liver are packaged into VLDL and exported into the circulation. The VLDL assembly requires ApoB and the assistance of MTTP, which facilitates the mobilization of $\mathrm{TG}$ into the microsomal lumen. In this study, we found that ApoB mRNA levels and MTTP protein levels did not differ, although MTTP mRNA levels were higher in steers than in bulls. Our results indicate that castration had minor effects on the hepatic expression of VLDL secretion genes. It has been reported that the ruminant liver is inefficient at exporting $\mathrm{TG}$ via secretion of VLDL compared to non-ruminants (Emery et al., 1992; Graulet et al., 1998; Katoh, 2002).

To study the effects of castration on gene expression levels of hepatic lipid metabolism, we sampled bulls and steers of normal slaughter age, which is 20 and 28 months of age, respectively, for Korean cattle. Thus, there are 8 month- difference in slaughter age between bulls and steers. Due to this age difference, it remains unclear whether the differences of lipid metabolism gene expression levels in this experiment result from different slaughter age between bulls and steers, or the effects of castration. Study using bulls and steers with same age will give better understanding of castration effects on lipid metabolic gene expression in the liver.

In this study, carcass weights were heavier in steers (398 $\mathrm{kg}$ ) than in bulls $(347 \mathrm{~kg})$. Thus, at slaughter, the mean body weight and feed intake levels in steers were higher than those in bulls. The expression level of lipid metabolism genes in liver is likely affected by feed intake levels. Therefore, it remains unclear whether the differences of lipid metabolism gene expression levels are due to different feed intake levels between bulls and steers, or the effects of castration.

\section{CONCNUSION}

We found that the livers of steers had higher lipid contents and lipogenic ACC mRNA levels, and mRNA levels of its regulator, SREBP1. In steers, de novo FA synthesis may be an important factor for fat accumulation in the liver. However, castration have not significantly affect hepatic lipid metabolism, including TG synthesis, FA oxidation, and VLDL secretion. Therefore, liver lipid metabolism may not have a significant role on increased 
body fat accumulation in steers after castration. Other peripheral tissues, including muscle and adipose tissues, may have major role on increased body adiposity after castration.

\section{ACKNOWLEDGMENTS}

This study was supported by a grant from the National Research Laboratory Program (ROA-2007-0056702), through the NRF, funded by the Ministry of Education, Science, and Technology, by Research Resettlement Fund for the new faculty of SNU, and by a grant from the NextGeneration BioGreen 21 Program (No. PJ00819103), Rural Development Administration, Republic of Korea.

\section{REFERENCES}

Anderson, N. and J. Borlak. 2008. Molecular mechanisms and therapeutic targets in steatosis and steatohepatitis. Pharmacol. Rev. 60:311-357.

Bonen, A., A. Chabowski, J. J. Luiken, and J. F. Glatz. 2007. Is membrane transport of FFA mediated by lipid, protein, or both? Mechanisms and regulation of protein-mediated cellular fatty acid uptake: Molecular, biochemical, and physiological evidence. Physiology (Bethesda, Md.) 22:15-29.

Bong, J. J., J. Y. Jeong, P. Rajasekar, Y. M. Cho, E. G. Kwon, H. C. Kim, B. H. Paek, and M. Baik. 2012. Differential expression of genes associated with lipid metabolism in longissimus dorsi of Korean bulls and steers. Meat Sci. 91:284-293.

Chen, X., X. Wang, Z. Li, L. Kong, G. Liu, J. Fu, and A. Wang. 2012. Molecular cloning, tissue expression and protein structure prediction of the porcine 3-hydroxy-3methylglutaryl-Coenzyme A reductase (HMGR) gene. Gene 495:170-177.

Edwards, P. A., M. A. Kennedy, and P. A. Mak. 2002. LXRs; oxysterol-activated nuclear receptors that regulate genes controlling lipid homeostasis. Vascul. Pharmacol. 38:249-256.

Emery, R. S., J. S. Liesman, and T. H. Herdt. 1992. Metabolism of long-chain fatty-acids by ruminant liver. J. Nutr. 122:832-837.

Folch, J., M. Lees, and G. H. Sloane Stanley. 1957. A simple method for the isolation and purification of total lipides from animal tissues. J. Biol. Chem. 226:497-509.

Goldberg, I. J. and M. Merkel. 2001. Lipoprotein lipase: physiology, biochemistry, and molecular biology. Front. Biosci. 6:D388-D405.

Graulet, B., D. Gruffat, D. Durand, and D. Bauchart. 1998. Fatty acid metabolism and very low density lipoprotein secretion in liver slices from rats and preruminant calves. J. Biochem. 124:1212-1219.

Grummer, R. R. 1993. Etiology of lipid-related metabolic disorders in periparturient dairy cows. J. Dairy Sci. 76:38823896.
Hausman, G. J., M. V. Dodson, K. Ajuwon, M. Azain, K. M. Barnes, L. L. Guan, Z. Jiang, S. P. Poulos, R. D. Sainz, S. Smith, M. Spurlock, J. Novakofski, M. E. Fernyhough, and W. G. Bergen. 2009. Board-invited review: the biology and regulation of preadipocytes and adipocytes in meat animals. J. Anim. Sci. 87:1218-1246.

Jeong, J., J. Bong, G. D. Kim, S. T. Joo, H. J. Lee, and M. Baik. 2013. Transcriptome changes favoring intramuscular fat deposition in the longissimus muscle following castration of bulls. J. Anim. Sci. 91:4692-4704.

KAPE. 2014. Korea Institute for Animal Products Quality Evaluation. http://www.ekape.or.kr/view/eng. 07-15-2014.

Katoh, N. 2002. Relevance of apolipoproteins in the development of fatty liver and fatty liver-related peripartum diseases in dairy cows. J. Vet. Med. Sci. 64:293-307.

Lin, H. Y., I. C. Yu, R. S. Wang, Y. T. Chen, N. C. Liu, S. Altuwaijri, C. L. Hsu, W. L. Ma, J. Jokinen, J. D. Sparks, S. Yeh, and C. Chang. 2008. Increased hepatic steatosis and insulin resistance in mice lacking hepatic androgen receptor. Hepatology 47:1924-1935.

Livak, K. J. and T. D. Schmittgen. 2001. Analysis of relative gene expression data using real-time quantitative PCR and the 2(Delta Delta C(T)) Method. Methods 25:402-408.

Loor, J. J., H. M. Dann, N. A. Guretzky, R. E. Everts, R. Oliveira, C. A. Green, N. B. Litherland, S. L. Rodriguez-Zas, H. A. Lewin, and J. K. Drackley. 2006. Plane of nutrition prepartum alters hepatic gene expression and function in dairy cows as assessed by longitudinal transcript and metabolic profiling. Physiol. Genomics 27:29-41.

Love-Gregory, L., R. Sherva, L. Sun, J. Wasson, T. Schappe, A. Doria, D. C. Rao, S. C. Hunt, S. Klein, R. J. Neuman, M. A. Permutt, and N. A. Abumrad. 2008. Variants in the CD36 gene associate with the metabolic syndrome and high-density lipoprotein cholesterol. Hum. Mol. Genet. 17:1695-1704.

Maltin, C., D. Balcerzak, R. Tilley, and M. Delday. 2003. Determinants of meat quality: tenderness. Proc. Nutr. Soc. 62:337-347.

Park, G. B., S. S. Moon, Y. D. Ko, J. K. Ha, J. G. Lee, H. H. Chang, and S. T. Joo. 2002. Influence of slaughter weight and sex on yield and quality grades of Hanwoo (Korean native cattle) carcasses. J. Anim. Sci. 80:129-136.

Shimano, H., N. Yahagi, M. Amemiya-Kudo, A. H. Hasty, J. Osuga, Y. Tamura, F. Shionoiri, Y. Iizuka, K. Ohashi, K. Harada, T. Gotoda, S. Ishibashi, and N. Yamada. 1999. Sterol regulatory element-binding protein-1 as a key transcription factor for nutritional induction of lipogenic enzyme genes. J. Biol. Chem. 274:35832-35839.

Van Den Top, A. M., T. Wensing, M. J. Geelen, G. H. Wentink, A. T. Van't Klooster, and A. C. Beynen. 1995. Time trends of plasma lipids and enzymes synthesizing hepatic triacylglycerol during postpartum development of fatty liver in dairy cows. J. Dairy Sci. 78:2208-2220. 